
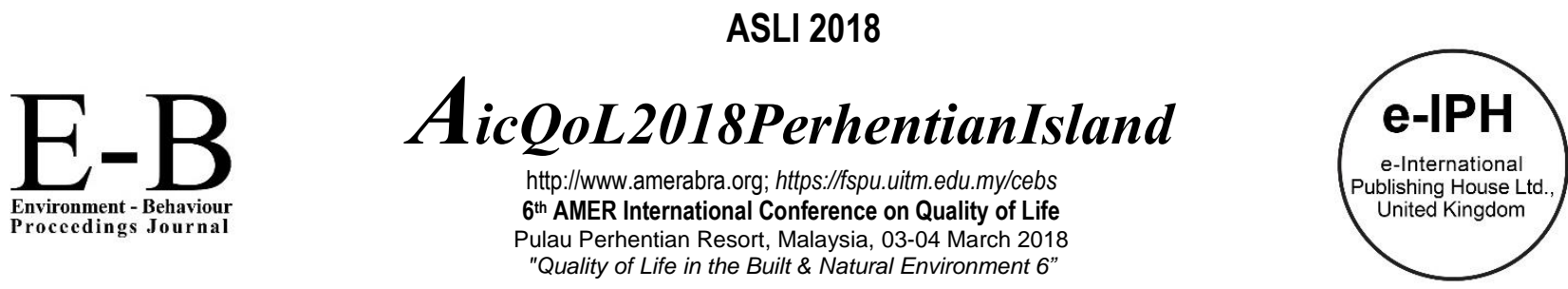

\title{
Urban Public Space Revitalisation Strategies for George Town World Heritage Site
}

\author{
Dasimah Omar ${ }^{1}$, Maimunah Ramlee ${ }^{2}$, Rozyah Mohd Yunus ${ }^{3}$, Zalina Samadi ${ }^{3}$ \\ ${ }^{1}$ Centre of Studies for Town and Regional Planning, Faculty of Architecture, Planning \& Surveying, \\ Universiti Teknologi MARA Kampus Puncak Alam, Selangor, Malaysia \\ ${ }^{2}$ Centre of Studies for Postgraduate Studies, Faculty of Architecture, Planning and Surveying, Universiti Teknologi MARA Shah Alam, Malaysia \\ ${ }^{3}$ Centre of Studies for Architecture, Faculty of Architecture, Planning \& Surveying, Universiti Teknologi MARA Kampus Puncak Alam, Selangor, Malaysia \\ dasimaho@yahoo.com, maimunahramlee@gmail.com, rodzy859@salam.uitm.edu.my, zalin628@salam.uitm.edu.my \\ Tel: +6013-914 4491
}

\begin{abstract}
Revitalization of urban public space is a mechanism to redevelop the public space area in Core Zone, George Town World Heritage Site (GTWHS) in accordance with the development growth and population. This paper discussed the factors of revitalization which are related to urban public space. The objectives of this paper are to analyze the characteristics of urban public space which could effectively be adopted for revitalisation purposes; and how to generate the public space more functional with positive influence on modern urban life. A combination of qualitative and quantitative research method was applied. The recommendations can contribute to improve the planning and management of urban public space in GTWHS, Pulau Pinang.
\end{abstract}

Keywords:Public space; Urban revitalisation; Revitalisation strategies

eISSN: 2398-4287C 2018. The Authors. Published for AMER ABRA cE-Bs by e-International Publishing House, Ltd., UK. This is an open access article under the CC BYNC-ND license (http://creativecommons.org/licenses/by-nc-nd/4.0). Peer-review under responsibility of AMER (Association of Malaysian Environment-Behaviour Researchers), ABRA (Association of Behavioural Researchers on Asians) and cE-Bs (Centre for Environment-Behaviour Studies), Faculty of Architecture, Planning \& Surveying, Universiti Teknologi MARA, Malaysia.

DOI: https://doi.org/10.21834/e-bpj.v3i7.1235

\subsection{Introduction}

After the Second World War, the urban revitalization was highlighted in the industrialized nations (Farzaneh, 2011). According to Couch, Sykes and Borstinghaus (2010), Western Europe and the United States were confronted with problems which were affected by the war such as economic downturn, social disorder and environmental degradation. Therefore Abdul Majeed (2012, p. 113), stated out that "rapid urbanization requires cities to be made livable and sustainable to optimize the potential of cities as the engines of economic growth". Thus, the concept of urban revitalization is important to redevelop the city centre.

With rapid development and urbanization in Malaysia, public spaces become inevitable components in urban areas which play an important role in social life of community. Public space also allows all peoples regardless from different background to use pubic space, to enjoy the nature and serve as gathering place for social activities and events. This is supported by Rostami, Lamit, Khoshnava and Rostami (2016) who claim that "public spaces are the necessary elements of the city that mainly influence the quality of the local environment, physical and ecological roles but also by contributing to the mental and psychological health of human beings" Moreover, this study aims to reveal the factors of revitalization which are related to urban public space in GTWHS. Thus, regarding this definition, public space fulfils users' need with different functions and features in urban area, remind us to think and create successful public space for individuals and families to enjoy it through revitalization strategies.

Recognizing the importance of the role and function of public spaces, the objectives of this paper are to analyze the characteristics of urban public space which could effectively be adopted for revitalization purposes, and through what medium to generate the successful and functionally public space with positive influence on modern urban life.

eISSN: 2398-4287@ 2018. The Authors. Published for AMER ABRA cE-Bs by e-International Publishing House, Ltd., UK. This is an open access article under the CC BYNC-ND license (http://creativecommons.org/licenses/by-nc-nd/4.0). Peer-review under responsibility of AMER (Association of Malaysian Environment-Behaviour Researchers), ABRA (Association of Behavioural Researchers on Asians) and cE-Bs (Centre for Environment-Behaviour Studies), Faculty of Architecture, Planning \& Surveying, Universiti Teknologi MARA, Malaysia.

DOI: https://doi.org/10.21834/e-bpj.v3i7.1235 


\subsection{Literature Review}

Public space sometimes can be understood as a gathering space (Kurniawati, 2012). Sakip, Mt Akhir and Omar (2015) have revealed that public space as a place for social interaction and engagements which reflect the problems and obstacles of its users. Following this, Qamaruz-Zaman, Samadi and NikAzhari (2013) noted that public space should be accessible from all sorts of background that provide various activities and functions which tend to be more attractive and livable public space through social activities to promote social interaction. In conducting this study, the conceptual framework was designed as a guide throughout study (Figure 1).

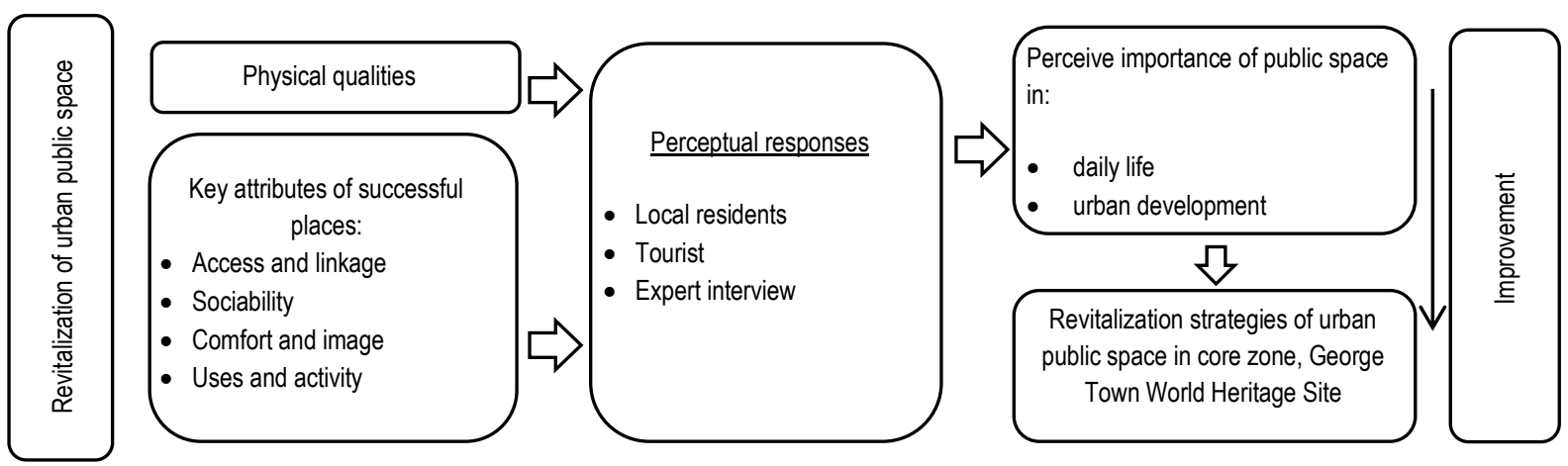

Fig. 1: Conceptual framework of the study.

According to Figure 1, the physical qualities are the important aspect of a place that create sense of place and contribute to the place's characteristics (Kusumowidagdo, Sachari \& Widodo, 2015). The study area located in core zone Goerge town world heritage site, whereby the placesurrounded with values and qualities that become worthy to be revitalized (Doratli, Hoskara \& Fasli, 2004). Besides, in evaluating public space as successful places that addressed by Project for Public Spaces [PPS] \& Metropolitan Planning Council [MPC], (2008), this study emphasizing the four key qualities: they are accessible, activities, comfortableand sociability. In addition, the people's perceptual responses were gathered from the survey questionnaire and expert interview. It is important in contributing the strategies for revitalisation of urban public space.

The development of public space in historic cities and urban areas in Malaysia involves rapid commercial development in historic sites which has negative impact that attracts many controversies for its preservation. Samadi and Yunus (2012, p. 343) found out that "the heritage revitalization arise from the issue of generalization due globalization in the early decade of the millennium". Apart from that, the value of public space is highlighted in historic area and usually use as a landmark which is identified as significant identity in historic site. Therefore, in tackling the impact of development in historic cities, revitalization is considered as the most adaptable strategies towards successful public space within the existing heritage sites.

Bagwell, Evans, Witting and Worpole (2012) revealed that public space revitalization strategies had been designed to bring intercultural communities together. There are several aspects need to be highlighted in this study in generating revitalization strategies of urban public space. Physical factor is an aspect can play a critical role in contributing the characteristics of public space as well as reflect the behaviour pattern and use (Ja'afar, Sulaiman \& Shamsuddin, 2012). The study area is in heritage site whereby the place as assets with worthy value and qualities to be preserved and revitalized. Therefore, this study also focused the key attributes of the successful places as suggested by Project for Public Spaces [PPS] \& Metropolitan Planning Council [MPC], (2008) who addressed four key qualities: they are Sociability

Access and linkage

Comfort and image

Uses and activity

According to Abdul Rahman, Shamsuddin and Ghani (2015), the human comfort or well-being is important in carrying out activities at public spaces which relates to the lively and comfortable environment for the people. Samadi and Yunus (2011) stated that landscape is important in physical attributes of revitalization to achieve human comfort at public space. This as Bagwell et al., (2012) explains that the physical setting involving the planning, designing, implementing and managing the landscape of urban public spaces for comfort, safety and enjoyment of people as well as having a strong symbolic and aesthetic dimension. Also, Nasution and Zahrah (2012) argued that good quality of urban space depends on the perception and satisfaction of human needs. In this case, information about users' perceptions and needs would be very useful for the further improvement of public space. Thus, the users' preferences and perceptions may assist in understanding the needs of users (Nasution \& Zahrah, 2015) as well as useful for the further improvement of public space.

Although the approach of revitalizing public space is commendable, fundamental change in urban revitalization should be inspired so that the heritage value of the historic cities is maintaining well. To achieve that, public preferences of the successful public space in the historic site must be integral part of the urban revitalization alongside the effective role of the government and stakeholders in the design and implementation of the policy (Said, Aksah \& Ismail, 2013). 


\subsection{Research Methodology}

\subsection{Methods}

In achieving the aim, this study applied mixed method approach where a combination of qualitative and quantitative research method was adopted. The qualitative method involved literature review, site observation and in-depth interviews. Meanwhile, the quantitative approach was based on questionnaire survey regarding public spaces' successful factors through the assessments by local residents and tourists. This paper presents the case study which covers the urban public space of Padang Kota Lama in George Town Word Heritage Site.

At first, the relevant concept of revitalization of urban public space and related variables were defined through preliminary study on literature review. Then, the physical condition and attributes of study area were collected through site observation. The next step was conducted the in-depth interviews that involve five respondents who are the experts in related field of this study. The data recorded and transcribed using content analysis. The expert interview is for deeper views and understanding of study. Finally, a field survey was implemented in data collection. There are three stages of survey method which involves questionnaire design, the sample of survey and data collection. The convenience method of non-probability sampling technique was applied in determining the sample size. The selfadministered survey was conducted for 400 samples of questionnaire for local residents and 100 samples questionnaire for tourists. The closed-ended question, numeric question and Likert Scale were used in questionnaire survey.

In carrying out this research, the limitation of the studyhad been recognized. The selected study area is based on the typologies of urban public space within GTWHS.

\subsection{Study area}

The selected study area is Padang Kota Lama, in Core Zone, George Town World Heritage Site (GTWHS), Pulau Pinang. Padang Kota Lama serves the area as urban park as well as historical site and waterfront area inscribed by UNESCO. It functions as an ideal place to relax with family while travelling in Pulau Pinang and main recreational and social centre for the residents in the evening and weekends. Figure 2 (a) and (b) shows the entrance and panoramic view of Padang Kota Lama. In addition, this area as visitors' attractions area and as a focus point area for daily activities such as fishing and busking at promenade walkways, basketball and sepak takraw game beside the Fort Cornwallis. According to Hajmirsadegh, Shamsuddin and Faroughi (2012), the devices and facilities as a physical attributes of public space which should be provided for the daily requires of people.

(a) (b)
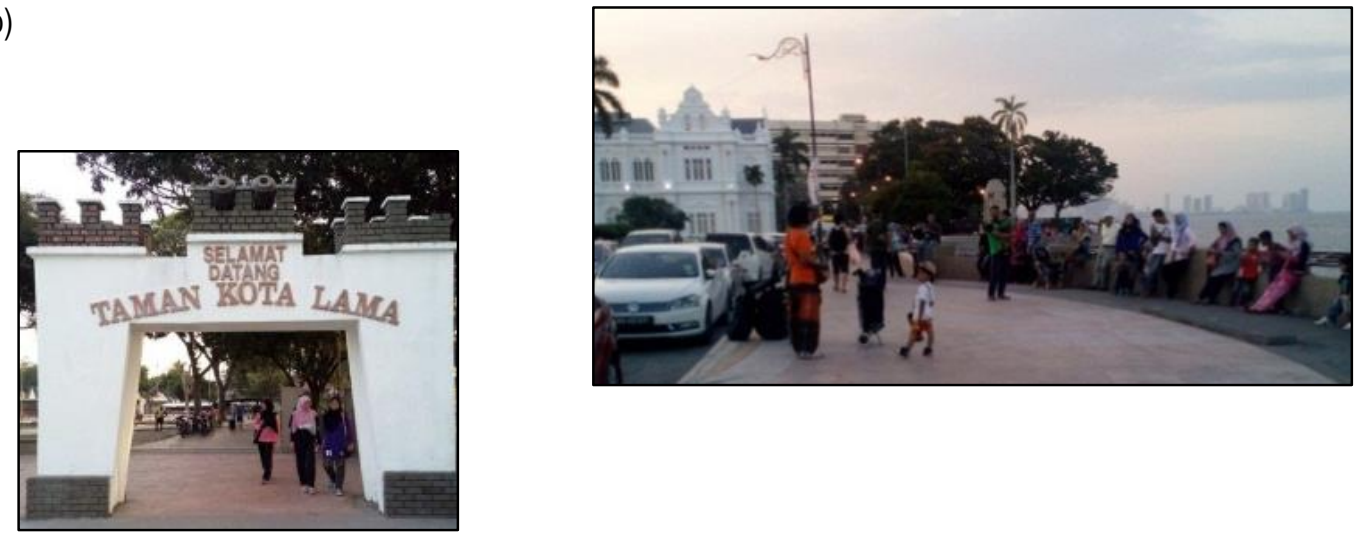

Fig.2. (a) Entrance to Padang Kota Lama; (b) Panoramic view of Padang Kota Lama.
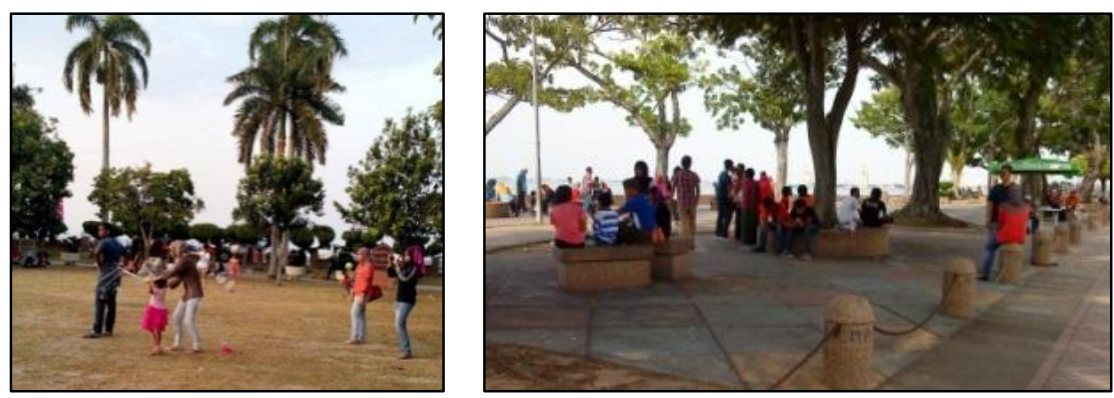

Fig. 3.Activities and users in Padang Kota Lama.

The study area is connecting with Jalan Padang Kota Lama, JalanTun Syed Sheh Barakbah and Lebuh Light. The study area surrounded by buildings and historic sites such as Fort Cornwallis, Esplanade, Town Hall, City Hall and Cenotaph. There are some facilities provided within the public space in connecting users with a place for their activities. It includes food court, promenade walkway, 
children playground, benches and basketball court. The urban park also serves as a venue for cultural festivals, celebrations, events and urban activities such as Penang Bon Odori Festival such as in Figure 3.

\subsection{Results and Discussions}

The analysis method for questionnaire survey was using SPSS Software. The analysis of questionnaire survey based on the demographic, behavioral pattern and respondents perceptions. The main focused of the analysis is to understand the characteristics of urban public space in heritage site according to each variable, which will add another layer of understanding the revitalization strategies of public space. However, additional attributes of respondents' profile such as respondents' gender, age group, race and home distance to public space were also analyzed to determine the purpose and interests of people came to study area. Meanwhile, the qualitative analysis wasanalyzed through content analysisthat based on the interview questions for the government officials and Non-Governmental Organization.

\subsection{Urban public space in daily life}

Public space users need to perceive the leisure and recreation activities by themselves as well as gain the benefits. In this aspect, public participation throughout the study is significant to contribute beneficial public space settings. Therefore, the public space users or community are the primary focus of this study. Public spaces as a place for people to carry out active and passive activities in their daily life. Also, the activities at public space will create variety of experience through social interaction. Urban pubic space is a vital part of modern urban life and has a significant impact on economic growth in either small or more significant urban centre.

Table 1. Descriptive analysis of purpose of visit

\begin{tabular}{llll}
\hline & Minimum & Maximum & Mean \\
\hline Relax & 2 & 5 & 4.2500 \\
Walk & 1 & 5 & 4.1400 \\
Outdoor activities & 1 & 5 & 3.9575 \\
Exercise & 1 & 5 & 3.4725 \\
Talking with friends & 1 & 5 & 3.7800 \\
For fresh air & 1 & 5 & 4.2800 \\
Have fun & 1 & 5 & 4.1225 \\
Making friends & 1 & 5 & 2.4975 \\
Doing nothing & 1 & 5 & 2.2100 \\
Getting information & 1 & 5 & 2.5950 \\
Escape from home & 1 & 5 & 1.1275 \\
Dating & 1 & 5 & 3.0450 \\
View city scenery & 1 & 5 & 3.8950 \\
Play with child & 1 & 5 & 3.1650 \\
\hline
\end{tabular}

The physical aspect of public space is interconnected with all elements in public space which often having node of activity (Namin, Najafpour \& Lamit, 2013). Table 1 shows the purpose of visiting the study area. Following this, the active and passive activities carried out are closely related with the place setting that foster better social interaction such as public space as a place for resting, jogging activities and sitting area; children activities with family; and create informal communication. Also, this is supported by in-depth interview, the Padang Kota Lama also as a most familiar urban park among local residents and tourists in GTWHS and hosts the weekly, monthly and yearly events. Thereby, the proper and suitable facilities are essential in connecting users and place as well as contributing clean, harmonious and attractive environment in their daily life.

\subsection{Public space and urban development}

The current urban development in Malaysia is emphasizing the provision of urban public space whereby it was becoming interesting phenomenon for the urban environment. Public space becomes essential part of the city design which is based on the needs and interests, especially for any form of activities or public events. Usually, people use the public space as a neighbourhood space, playground, square or park, as a gathering space to promote sense of community and social interaction. Besides it serves as gathering space, public space could also play important roles in matters of the public and urban areas.

Rosly and Abdul Rashid (2013) reported that the revitalization of urban public space in GTWHS has been introducing to generate new ideas and impetus. Moreover, the establishment of public space could meet the needs and demands of users to improve the aesthetic features and city's economic. From the findings, the effects of urban public space on urban development have been highlighted. According to quantitative analysis, $70 \%$ findings have highlighted the effect of urban public spaces on urban development in study area. As such, public space could improve the urban environment, improve vitality, improve economic and tourism development, forms a public space culture, enhance city image, and improve liveliness in urban development. Also, from in-depth interview acknowledge that the revitalization strategies of public space require good and pleasant coordination between the departments and agencies. Urban public space serves as a stage of urban life when it functions run smoothly. Therefore, urban public space can be considered as public activities of city centre and closely related to improving urban development. 


\subsection{Physical planning of public space}

Abdul Aziz (2012) explained that physical environment and settings are connected with physical activity behaviour including duration, type and frequency. Nasution et al., (2012) clarified that physical dimension of public space should be clear and easy access to create human comfort and safe movement system whereby it encourages people either locals or foreigners to get to urban park. Regarding place, public space plays important role as physical component in developing revitalization strategies. This is supported by Wan Ismail and Said (2015) whereby studies on the people's perceptions and behaviour toward public space began to explore the definition of the place to inform the planning process.

In planning of public space which is located in GTWHS, it should emphasize the historical site, cultural setting (Nik Mohammad, Saruwono, Said \& Wan Hairi, 2013), natural context and human needs to maintain the place. In creating the sense of place, all the valuable components in heritage site value cannot be destroyed and should be preserved so that future generation can recognize, learn and experience the area by looking at the physical components (Kusumowidagdo et al., 2015). As Nik Mohammad et al. (2013), stated that place could play a critical role as space between users and environment setting for revitalization strategies.

In other perspectives, landscape is a physical aspect of public space planning that relates to soft and hardscape; active and passive green; and street furniture (Samadi et al., 2012). Elements of landscape and green area are significant in built environment which can create a place as a space to interact with each other and to feel the authenticity of public space in heritage site. As described by Namin et al. (2013), landscape features can increase the opportunity for social engagement and interaction among public space users while enjoying the peaceful landscapes. In designing public space, it should emphasize the physical setting of place with all design aspects and beautification of the landscape. Also, the landscape setting can improve the quality of life by providing a comfortable environment and can give a boost to urban life simultaneously as a catalyst for social interaction (Nasution et al., 2012).

According to quantitative analysis, half of the respondents from the questionnaire survey highlighted the lack of natural features at the study area. In addition, the shoddy landscaping works is unsafe for children to play.From the findings in Table 2, it reveals the lack of natural features which lead to the less functioning of public space facilities such as pedestrian walkway and bicycle trail about climate and air quality of the urban environment. As supported by Ja'afar et al. (2013), who stated that soft landscape does not just feature of public space for physical planning, but encompass the hard landscape features and street furniture such benches, lighting, signage and bicycle racks. Following this, Zendehdelan, Pouyanfar and Ahmad (2013) pointed that the design quality of public space landscaping should clarify the roads circulation, entrances, space environment to create sense of place and to establish continuity in public space. The elements of landscape can portray the identity of study area in GTWHS.

Table 2.Descriptive analysis of perceptions on facilities and street furniture in public space.

\begin{tabular}{llll}
\hline Perception & Minimum & Maximum & Mean \\
\hline Pedestrian walkways fully connected & 2 & 5 & 4.1150 \\
Clean and good condition of public toilet & 1 & 5 & 3.5150 \\
Sufficient parking space & 1 & 5 & 2.8500 \\
Comfort and safety gazebo & 1 & 5 & 1.9000 \\
Comfortable design and suitable benches & 1 & 5 & 3.8050 \\
Appropriate location, design and maintenance aspects of dustbins & 1 & 5 & 3.7575 \\
Sufficient lighting for safety and security & 1 & 5 & 3.6850 \\
Informative signage & 1 & 5 & 3.7075 \\
Safe and attractive playground & 1 & 5 & 3.5750 \\
Aesthetically pleasing with natural features & 1 & 5 & 2.6750 \\
\hline
\end{tabular}
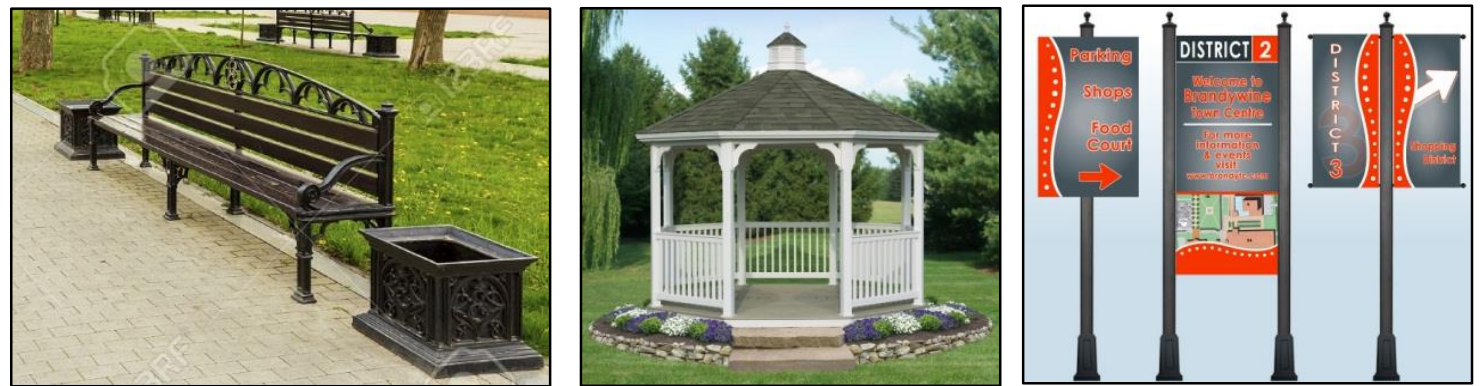

Fig.4.Examples of street furniture in public space

Several studies explore that access and linkage about the human needs and comfort at public space. This aspect is important to ensure the convenience of users whereby it serves as accessibility to all facilities in the public space. This view is supported by Rosly et al. (2013) that developments should highlight the user's comfort, integrated with the surrounding urban fabric to create continuity in the public realm, green spaces and pedestrian networks. It means that physical planning of public space should emphasize the comfort and safety features so that the users will continuously and spontaneously use the public space without coercion. Figure 4 shows the examples of street furniture in public space. 


\subsection{Management approach in public space}

Public spaces have been developed by managers and local authorities to provide opportunities for people to benefit from them (Shuib, Hashim \& MohdNasir, 2015). Given this, the good strategies and actions are important to improve consciousness, awareness and promote respect in using public spaces by keeping them clean, suggesting new events and activities (Namin et al., 2013). The management services of public space can be improved through integrated and productive management; and exciting promotion so that it can increase the number of users at public space. The aspects of cleanliness and maintenance should be improved to avoid abandoned area. According to qualitative analysis, all respondents suggested that comprehensive management and good cooperation is important in terms of responsibility and coordination between the government and agencies which involved directly or indirectly in the management of urban public space in the GTWHS.

In other perspectives, the management of public space should also emphasize on the public facilities to meet the needs and satisfaction of users. Since there are different needs and demand of users, the management party should be able to predict the types and levels of users' needs. According to Rosly et al. (2013), stated that the initiative of funding management also implemented in revitalization strategies. This approach is useful in monitoring the implementation and management of public space in GTWHS which includes matters about promotion, branding, tourism, public transport, safety, research, impact studies, public awareness and provide advisory services related to heritage sites (GTWHI, 2014). Hence, all the related agencies should have good cooperation and collaboration in revitalization strategies of public space.

\subsection{Conclusion}

Public space offers excellent benefits towards enhancing quality of urban life. While many efforts have been applied to ensure public space characteristics achieve the users' needs and demand, studies on how revitalization strategies provide benefits for urban public space planning is fundamental. Local residents and tourists in public space revitalization strategies play a vital role to ensure public space benefits were delivered comprehensively and effectively. Literature review, in-depth interviews, questionnaire surveys and public meetings are among the research instrument to gather views and perceptions of the users.

Following that, the several recommendations have been established from the discussion and findingsof the qualitative and quantitative analysis of this study. All the recommendations are in line with the three objectives of the study. Generally, the recommendations are also considering the policy and guidelines in the aspect of planning. Therefore, this study aims to assess and improve revitalization of urban public space in core zone, GTWHS. This study describes on how revitalization strategies assist towards urban public space. This kind of study could be useful to determine the success of the public space, particularly for planners, local authority and management party. In the broader context, this study is beneficial and applicable to enhance the management and planning of public space to meet the users' needs and demands.

\section{Acknowledgements}

The authors would like to acknowledge the Research Management Institute of UniversitiTeknologi MARA. The highest appreciation goes to the co-researchers who had to guide and supporting for preparing this paper.

\section{References}

Abdul Aziz, N. A. (2012). Green space use and management in Malaysia.Forest \& Landscape Research, 51(2012), 1-71.

Abdul Majeed, H. (2012). Urban regeneration: The case of Penang, Malaysia putting policy into practice. Retrieved from http://siteresources.worldbank.org//NTCHD/Resources/MalaysiaBBL2.pdf

Abdul Rahman, N., Shamsuddin, S., \&Ghani, I. (2015). What makes people use the street?: Towards a liveable urban environment in Kuala Lumpur city centre. Procedia - Social and Behavioral Sciences, 170(2015), 624-632.

Bagwell, S., Evans, G., Witting, A., \&Worpole, K. (2012). Public space management report to the intercultural cities research programme. Retrieved from $\mathrm{https} / / / \mathrm{rm}$.coe.int/CoERMPublicCommonSearchServices/DisplayDCTMContent?documentld=09000016803009c0

Couch, C., Sykes, O., \&Borstinghaus, W. (2010). Thirty years of urban regeneration in Britain, Germany and France: The importance of context and path dependency. Progress in Planning, 75(2011), $1-52$.

Doratli, N., Hoskara, S. O., \&Fasli, M. (2004). An analytical methodology for revitalization strategies in historic urban quarters: A case study of the Walled City of Nicosia, North Cyprus. Cities, 21(4), 329-348.

Farzaneh, M. (2011). Urban Development Planning, Regeneration and Public Participation: A Comparison Between the UK and Iran. Newcastle University, United Kingdom.

George Town World Heritage Incorporated. (2014). George Town Special Area Plan. Retrieved from http://www.gtwhi.com.my/resource/important-documents/georgetown-special-area-plan.html

Ja'afar, N. H., Sulaiman, A. B., \&Shamsuddin, S. (2012). The contribution of landscape features on traditional streets in Malaysia. Procedia - Social and Behavioral Sciences, 50(2012), 643-656. 
Kurniawati, W. (2012).Accommodative Study of Public Space for Marginalized People.Asian Journal Of Environment-Behaviour Studies, 3(10), 1-10.

Kusumowidagdo, A., Sachari, A., \&Widodo, P. (2015).Visitors' perception towards public space in shopping center in the creation sense of place.Procedia - Social and Behavioral Sciences, 184(2015), 266-272.

MdSakip, S. R., Mt Akhir, N., \& Omar, S. S. (2015).Determinant factors of successful public parks in Malaysia.Procedia - Social and Behavioral Sciences, 170(2015), 422-432.

Namin, E. R., Najafpour, H., \&Lamit, H. (2013). Public places and spaces and social urban interaction (A case study of Johor Bahru, Malaysia). International Journal of Current Engineering and Technology, 3(2), 281-291.

Nasution, A. D., \&Zahrah, W. (2012).Public open space privatization and quality of life, case study Merdeka Square Medan.Procedia - Social and Behavioral Sciences, 36(2012), 466-475.

Nasution, A. D., \&Zahrah, W. (2015). The Space is not ours, the life of public open space in gated community in Medan, Indonesia. Procedia - Social and Behavioral Sciences, 202(2015), 144-151.

Nik Mohammad, N. M., Saruwono, M., Said, S. Y., \& Wan Hariri, W. A. H. (2013). A sense of place within the landscape in cultural settings.Procedia - Social and Behavioral Sciences, 105(2013), 506-512.

Project for Public Spaces \& Metropolitan Planning Council. (2008). What makes a place great? A neighborhood guide to placemaking in Chicago. Retrieved January 4, 2016, from http://www.placemakingchicago.com/about/great.asp

Qamaruz-Zaman, N., Samadi, Z., \&NikAzhari, N. F. (2013). Under the flyovers of Kuala Lumpur: User centered activities in leftover spaces. Journal of Asian Behavioura Studies, 3(10), 89-103.

Rosly, D., \& Abdul Rashid, A. (2013).Revitalizing urban development in Malaysia through the implementation of urban regeneration programme.Perspective on Urban Redevelopment, 1-20.

Rostami, R., Lamit, H., Khoshnava, S. M., \&Rostami, R. (2016). Successful public places: A case study of historical Persian gardens. Urban Forestry \& Urban Greening 15(2016), 211-224.

Said, S. Y., Aksah, H., \& Ismail, E. D. (2013).Heritage conservation and regeneration of historic areas in Malaysia.Procedia - Social and Behavioral Sciences, 105(2013), $418-428$.

Samadi, Z. \&Yunus, R. M. (2011). Urban heritage streets' revitalising attributes. Asian Journal of Environment-Behaviour Studies, 3(7), 69-78.

Samadi, Z., \&MohdYunus, R. (2012). Physical and spiritual attributes of urban heritage street's revitalization. Procedia - Social and Behavioral Sciences, 36(2012), 342349 .

Hajmirsadeghi, R. S., Shamsuddin. S., \&Foroughi, A. (2012). The impact of physical design factors on the effective use of public squares. International Journal of Fundamental Psychology \& Social Sciences, 2(3), 49-56.

Shuib, K. B., Hashim, H., \&MohdNasir, N. A. (2015).Community participation strategies in planning for urban parks.Procedia - Social and Behavioral Sciences, 168(2015), $311-320$.

Wan Ismail, W. A., \& Said, 1. (2015). Integrating the community in urban design and planning of public spaces: A review in Malaysian cities. Procedia - Social and Behavioral Sciences, 168(2015), 357-364.

Zendehdelan, A., Pouyanfar, E., \& Ahmad, H. (2013). The perception of the sense of place in public spaces' quality through the five senses: "Case study of Naqsh-eJahan Square, Isfahan, Iran". Journal of Basic and Applied Scientific Research, 3(2), 1012-1020. 